\title{
Świadectwa
}

\section{Psychoanaliza i utopia}

Emanuel Berman

TEKSTY DRUGIE 2018, NR 1, S. 374-388

DOI: $10.18318 /$ td.2018.1.21

\section{Drogie Koleżanki i Drodzy Koledzy,}

to zaszczyt i przyjemność przemawiać dzisiaj w tym miejscu. Będę mówić po polsku, w moim ojczystym języku, chociaż nie władam nim perfekcyjnie. Wyjechałem z Polski w wieku czterech lat. Zawsze byłem do niej przywiązany i pozostała częścią mojej tożsamości. Moi rodzicie przeżyli wojnę w Warszawie. Byli działaczami podziemia, którzy uciekli z getta i po aryjskiej stronie przyjęli fałszywą tożsamość. Mój ojciec - Adolf Berman - do ostatnich swoich dni zachował dobre stosunki z wieloma polskimi przyjaciółmi, którzy ryzykowali życie, pomagając Żydom ściganym przez nazistów i kolaborantów.

Ponadto, w pierwszej dekadzie tego stulecia z przyjemnością podjąłem się zadania - z ramienia Międzynarodowego Towarzystwa Psychoanalitycznego - wspierania inicjatywy odrodzenia psychoanalizy w Polsce. Onowiło to mój kontakt z krajem i jego kulturą.

Od wielu lat interesują mnie relacje i paralele między trzema ruchami, które rozkwitły w pierwszych dekadach $\mathrm{XX}$ wieku, w okresie, na którym koncentruje się nasza

\section{Emanuel Berman}

- dr, psychoanalityk szkoleniowy i superwizor w Izraelskim Towarzystwie Psychoanalitycznym (IPA) oraz członek honorowy Polskiego Towarzystwa Psychoanalitycznego, emerytowany wykładowca na Uniwersytecie w Hajfie. Laureat nagrody Sigourney. Redaktor książki Essential Papers on Literature and Psychoanalysis (1993), autor Impossible Training: A Relational View of Psychoanalytic Education (2004). 
konferencja: mianowicie między marksizmem, syjonizmem i psychoanali$\mathrm{zą}^{1}$. Zainteresowanie to ma korzenie w moim życiu, ponieważ mój ojciec był marksistą, syjonistą i psychologiem ${ }^{2}$. Na pewno wpływa to na moją empatię wobec szlachetnych marzeń o przyszłości ludzi pokolenia mojego ojca. Rezultaty tych marzeń okazały się jednak bardziej skomplikowane i paradoksalne, niż się na początku spodziewano; my musimy je poddać rzetelnej analizie.

Doszedłem do wniosku, że we wszystkich trzech ruchach zawarty był element utopii, w dobrym i złym znaczeniu tego słowa. U podstaw utopizmu leży głębokie i zaangażowane dążenie do ulepszenia ludzkiego życia. Zawiera on jednocześnie elementy zaprzeczenia i iluzji, które mogą powodować skutki przeciwne do zamierzonych.

Elementy utopijne w wizji Marksa o równości i sprawiedliwości społecznej odgrywały dużą rolę w drodze do ucisku, do procesów moskiewskich i do powstania gułagów. Elementy utopijne w syjonistycznej wizji niepodległego państwa żydowskiego - szczególnie ślepota na jego wpływ na palestyńskich Arabów - przyczyniły się do działań wojennych i rozlewu krwi na Bliskim Wschodzie. Chociaż psychoanaliza nigdy nie doprowadziła do utraty ludzkiego życia, to jej elementy utopijne przyczyniły się, według mnie, do wielu problemów w organizacjach psychoanalitycznych oraz w programach szkoleniowych.

Wspomnę jeszcze jedną stronę osobistego tła moich poglądów. Moje oddanie nowatorskim, rewolucyjnym i wyzwalającym aspektom psychoanalizy jest konsekwencją mojego lewicowego zaangażowania politycznego z okresu dojrzewania i lat studiów. Ale jednocześnie otrzymałem w mojej młodości kilka trzeźwiących lekcji, które wpłynęły na moje opinie także o psychoanalizie. Dowiedziałem się, jak niebezpieczne są autorytarna pewność i dogmatyzm. Nauczyłem się, jak destruktywne są sekciarskie podziały, oparte na narcyzmie małych różnic. Dowiedziałem się, jak elitaryzm prowadzi do alienacji, jak izolacja przygniata.

Kocham wiele podstawowych aspektów psychoanalizy: nieustraszone samokrytyczne badanie własnej osobowości i życia, nieustające podważanie

1 Tekst tego artykułu został wygłoszony na międzynarodowej konferencji „Między nadzieją i rozpaczą. Dzieje psychoanalizy w Polsce w polsko-żydowsko-niemieckim kontekście kulturowym 1900-1939" w maju 2017 roku na Uniwersytecie Pedagogicznym w Krakowie W przekładzie niemieckim ukaże się on w książce Zwischen Hoffnung und Verzweiflung. Psychoanalyse in Polen im polnisch-deutsch-jüdischen Kulturkontext 1900-1939, Hrsg. von. P. Dybel, E. Kobylińska-Dehe, L.M. Hermanns, Psychosozial-Verlag, Giessen 2018

2 Chociaż bliżej mu było do Adlera niż do Freuda. 
truizmów i konwenansów, próbę nawiązania szczerej, ciepłej i otwartej relacji z drugą osobą. Jednak jestem krytyczny wobec wielu powszechnych, charakterystycznych cech organizacji i instytutów psychoanalitycznych: skłonności do konserwatyzmu, kontroli nad praktykantami i członkami, struktury władzy i hierarchii, wobec trzymania się ortodoksyjnych przekonań co do tego, co jest ,analityczne”, a co jest „nieanalityczne”, i do niepodważalnych zasad, które muszą kierować leczeniem, pozbawiając je jego naturalnej spontaniczności.

Chciałbym dziś zająć się związkiem między psychoanalizą i myślą utopijną na dwóch powiązanych ze sobą płaszczyznach: psychoanaliza jako narzędzie do zrozumienia utopijnego punktu widzenia, ale także elementy utopijne w samej psychoanalizie ${ }^{3}$. Wierzę, że tylko uznając i badając utopijne aspekty naszej dyscypliny, możemy ją skutecznie wykorzystać do empatycznego i zarazem krytycznego badania utopizmu - nie „z góry” jako niezaangażowani naukowcy udający bezstronność, ale od wewnątrz jako ludzie, których wprawdzie łatwo zwabić i omamić, ale którzy potrafią zdobyć się na taką perspektywę, aby zauważyć naturę tej przynęty i dostrzec ryzyko, jakie ze sobą niesie.

Dwaj wybitni francuscy psychoanalitycy, Janine Chasseguet-Smirgel i Béla Grunberger ${ }^{4}$ dokonali wnikliwej obserwacji: „To paradoks freudowskiej psychoanalizy, że ta, zmagając się nieustannie z iluzją, w pewien sposób ją uruchamia". Odnajdują ten paradoks w pracach Wilhelma Reicha, podkreślając różnice między nim a Freudem, który, jak uważają, nie ma utopijnych iluzji. Według mnie wyolbrzymiają te różnice. Nasuwa się następująca analogia: Marks widział samego siebie jako wroga utopizmu, ale jak Ernest Bloch i inni badacze wykazali ${ }^{5}$, elementy utopijne niewątpliwie występują w marksistowskiej teorii.

Sam Freud, z całym swoim konserwatywnym sceptycyzmem, nie był na temat utopii uodporniony. Weźmy np. jego przewidywania, że wpływ psychoanalizy zupełnie zredukuje problem wyparcia. Pisał: „Sukces w leczeniu jednostki musi nastąpić i okazać się w równomiernym stopniu sukcesem

E. Berman Psychoanalysis, rescue and utopia , Utopian Studies" 1993 No. 4, s. 44-56.

4 J. Chasseguet-Smirgel, B. Grunberger Freud or Reich?, Yale University Press, New Haven 1986, S. 14 .

5 W. Hudson The Marxist Philosophy of Ernest Bloch, Macmillan, London 1989; S. Lukes Marxism and Utopianism, w: Utopias, ed. by P. Alexander, R. Gill, Open Court, La Salle, IL. 1984, s. 153-167. 
dla społeczności”. Wyraził nadzieję, że „wszelka energia zużywana dzisiaj na produkcję objawów nerwicowych karmiących świat fantazji odizolowanych od rzeczywistości, będzie [...] pomagała wzmocnić głośne żądania zmian w naszej cywilizacji, dzięki którym możemy oczekiwać lepszej przyszłości następnych pokoleń"”.

Sądzę, że podstawowym źródłem skłonności psychoanalityków i psychoterapeutów do popadania w utopie są fantazje ratunkowe, które stanowią główną składową motywacji (możliwe, że nieuświadomioną), by zostać analitykami i terapeutami.

Historia pojęcia fantazji ratunkowej ukazuje potencja zawodowychi intelektualnych tradycji, które - wydaje się - są odporne na ślepe uliczki, na które wkracza niekiedy świat zewnętrzny. Kiedy Freud ${ }^{\mathbf{8}}$ po raz pierwszy omawiał zjawisko fantazji ratunkowych, odnosiło się ono do pewnych, szczególnych pacjentów - mężczyzn, których życie emocjonalne koncentrowało się na ratunku „kobiet upadłych". Jego interpretacja poszła linią edypalną: kobieta jest nieświadomie postrzegana jako matka, a uratowanie jej od seksualnego wykorzystywania oznacza zwycięstwo nad edypalnym ojcem. Jednak trochę czasu zabrało zdanie sobie sprawy z faktu, że fantazje ratunkowe mogą mieć znaczenie w naszym własnym zawodzie. Ferenczi ${ }^{9}$ był najbliżej tego odkrycia, kiedy opisał sytuację, gdy terapeuta „nieświadomie uczynił z samego siebie opiekuna swojego pacjenta lub jego rycerza-wybawcę", a pacjent to wyczuwa. Dopiero pół wieku później Phyllis Greenacre zdefiniowała koncepcję fantazji ratunkowych nadgorliwych analityków jako wyraz ich własnego wizerunku w roli zastępczego rodzica dla pacjenta. „W takich akcjach ratunkowych agresja analityka może być skierowana na tych krewnych pacjenta lub jego terapeutów [...], którzy przyczynili się, w rzeczywistości lub w fantazjach, do powstania zaburzeń. Analityk staje się więc zbawicielem"10.

W ostatnich latach wiele uwagi poświęcono fantazjom ratunkowym terapeutów zgodnie z rosnącą wśród współczesnych psychoanalitycznych

6 S. Freud The future prospects of psycho-analytic therapy „ "Standard Edition” 1910, No. 11, s. 148.

7 Tamże, s. 150.

8 S. Freud A special type of choice of object made by men, „Standard Edition” 1910, No. 11, S. $165-175$.

9 S. Ferenczi On the technique of psycho-analysis, 1919, w: Further Contributions to the Theory and Technique of Psycho-Analysis, Brunner/Mazel, New York 1980. 
autorów tendencją do skupiania się na życiu emocjonalnym analityków oraz na przeciwprzeniesieniu. Środek ciężkości w wyjaśnianiu zjawisk przeniósł się z edypalnego trójkąta na najwcześniejsze więzi z matką, na doświadczenie straty, na naprawę szkód wyrządzonych przez agresję, na potrzebę ratowania depresyjnego lub bezradnego rodzica oraz na uratowanie siebie samego za pomocą projekcji siebie na innych.

Oczywiście można by zapytać, czy istnieje jakakolwiek terapia bez fantazji ratunkowych? Moja odpowiedź na to pytanie jest ambiwalentna. Tak, fantazja ratunkowa może być konieczną siłą motywacyjną, jednak może też stać się przeszkodą, ponieważ czasami wchodzi w konflikt ze skuteczną profesjonalną pomocą. Można wymienić kilka podstawowych różnic między stanem umysłu zdominowanym przez nierafinowaną fantazję ratunkową a postawą, w której fantazja ta przekształca się w realny materiał do pracy terapeutycznej:

1. Omnipotencja. Wewnątrz fantazji ratunkowej możemy sami zmienić życie pacjenta z nieszczęśliwego na radosne. Rzeczywista i realna pomoc może wymagać postawienia sobie skromniejszych celów.

2. Idealizacja siebie i romantyzacja. Fantazja ratunkowa przedstawia terapeutę jako oddanego pracy altruistycznej; może więc zablokować świadomość naszych własnych ograniczeń i egocentrycznych motywacji, a także wewnętrznych konfliktów związanych z wymagającą wiele wysiłku i poświęcenia ciężką pracą.

3. Demonizowanie winnej strony - np. rodziców pacjenta lub innej figury - przez podział na dobrych i złych, winnych i niewinnych.

Z powodu tych czynników nieograniczona fantazja ratunkowa może nas zaślepić na całą złożoność procesu terapeutycznego, na ambiwalencję obu stron, a także na potencjalne paradoksalne wyniki procesu. Paradoks fantazji ratunkowych dobrze widać na przykładzie mitu o Orfeuszu i Eurydyce. Orfeusz ratuje ukochaną z piekła, ale posyła ją tam z powrotem, ponieważ łamie zakaz patrzenia na nią. To, co przez chwilę wydawało się wszechmocnym zwycięstwem, prowadzi ostatecznie do kruchnego i ułomnego - a więc ludzkiego - wyniku.

Fantazje ratunkowe stanowią istotny wątek filmu Zawrót gtowy Hitch$\operatorname{cocka}^{11}$. Bohater filmu, Scottie, jest detektywem, ale jego emocjonalny świat przypomina świat terapeuty zdominowanego przez fantazję ratunkową.

11 E. Berman Hitchcock's Vertigo: The collapse of a rescue fantasy , International Journal of Psychoanalysis" 1997 No. 78, s. 975-996. 
W pierwszej części filmu wierzy, że ratuje tajemniczą bohaterkę, Madeline, od mrocznego przeznaczenia. Imponujące są jego oddanie i samopoświęcenie. Dopiero później dowiadujemy się, że naiwne i romantyczne poglądy Scottiego doprowadziły do klęski. W istocie był on tak samo samotny i bezradny, jak kobieta, której starał się pomóc. Zrozumiał w sumie niewiele i nie dostrzegł większej i głębszej prawdy ukrytej za tajemnicą. W rzeczywistości został oszukany przez łajdaka, ale w akcie desperackiej próby uwolnienia się od kłamstwa, staje się tak samo okrutny jak ów łajdak. W końcu wysiłki Scottiego, aby dojść do prawdy i uratować kobietę, którą kochał, prowadzą do jej zniszczenia.

Definitywny podział ról między walecznego rycerza, bezradną i prześladowaną Piękną i straszliwego smoka jest znakiem rozpoznawczym fantazji ratunkowej. Kiedy ochłoniemy, odkrywamy, że wszyscy partnerzy w rozegranym dramacie są ludzcy, a zatem bardziej podobni do siebie nawzajem, niżby się wydawało na pierwszy rzut oka. „Wybawca” może być tak samo bezradny jak „Piękna” i równie agresywny jak „Smok”. Fantazja ratunkowa, której ulegają terapeuci, doprowadziła do rozwoju fantazji o idealnym rodzicu zastępczym, co stoi w sprzeczności z przyjętym przez nas założeniem, że terapeuta niechybnie przyjmuje problematyczne role osób występujących w życiu analizowanego, często poprzez identyfikacje projekcyjne. Jedynie pełna świadomość tych sił, a nie zaprzeczanie im przez romantyczne idealizowanie siebie - może pozwolić nam w końcu je opanować.

Utopizm opiera się na uogólnionej wersji fantazji ratunkowej, gdzie ludzkość (lub poszczególne narody albo klasy społeczne) wchodzi w rolę ofiary, która musi zostać uratowana. Wilhelm Reich jest dobrym przykładem analityka, z którego dorobku wyłania się potężna fantazja ratunkowa i wizje utopijne.

Poglądy Reicha wzbudzały wrogość Freuda. Sterba ${ }^{12}$ opisuje dyskusję podczas spotkania w Wiedeńskim Towarzystwie Psychoanalitycznym w 1929 lub 1930 roku. Reich - który był również komunistą - pochwalał rosyjski eksperyment zabierania niemowląt z rodzin i wychowywania ich w publicznych placówkach, co według Reicha pozwalało zapobiec rozwojowi silnego przywiązania do rodziców. Sterba cytuje odpowiedź Freuda: „[Reich - przyp. E.B.] twierdzi, że jeśli w Rosji na stałe zabroni się małżeństw i zakładania rodziny, nie nastąpi rozwój kompleksu Edypa, a w konsekwencji nie będą

12 R.F. Sterba Reminiscences of a Viennese Psychoanalyst, Wayne State University Press, Detroit 1982. 
występowały nerwice. To można porównać do leczenia problemów jelitowych poprzez zakaz jedzenia i wsadzenia korka w odbyt"13.

Ograniczony czas nie pozwala mi na analizę fantazji ratunkowych i elementów utopijnych w pracy innych myślicieli, pozostających - podobnie jak Reich - pod wpływem Freuda i Marksa, takich jak Fromm czy Marcuse, którzy rozwinęli przeciwstawne wizje, jednak obaj mieli nadzieję na świat bez konfliktu i frustracji ${ }^{14}$. Przedstawię teraz eksperyment - podobny do sowieckiej metody tak podziwianej przez Reicha - który był wynikiem wpływów marksizmu, syjonizmu i psychoanalizy: wychowanie wspólnotowe we wczesnym ruchu kibucowym.

Izraelski kibuc był traktowany przez Bubera i innych myślicieli jako realizacja utopii. System edukacyjny w kibucu był tworzony pod wpływem idei psychoanalitycznych ${ }^{15}$. W klasycznej wersji wychowania wspólnotowego w kibucu wszystkie dzieci żyły i już od pierwszych tygodni życia mieszkały w specjalnym domu przeznaczonym dla dzieci. Były rozdzielane na małe grupy, każda ze specjalną opiekunką. Rodziców dzieci widywały raz dziennie, podczas krótkich popołudniowych wizyt.

Rola psychoanalizy była szczególnie widoczna w Haszomer Hatzair, ruchu znajdującym się bezpośrednio pod wpływem Freuda i Marksa, począwszy od lat 20. XX wieku. Zacytuję tutaj zdanie z ich programu: „po zaciętej walce toczonej w naszym ruchu [...] uniknęliśmy niebezpieczeństwa związanego ze spaniem dzieci razem z rodzicami; [...] zagrożenia z tym związane ujawniła i potwierdziła nowoczesna psychologia"16.

Nacisk położony na zagrożenie i niebezpieczeństwo sugeruje fantazję ratunkową. Miano nadzieję „położyć kres patogennemu pomostowi między pokoleniami". Przed czym chciano ratować dzieci? Posługiwano się trzema psychoanalitycznymi argumentami:

1. Dzieci powinny być trzymane $\mathrm{z}$ dala od sypialni rodziców, aby uniknąć patogennych i traumatycznych efektów obserwacji seksualnych zachowań rodziców.

13 Tamże, s. 111.

14 E. Berman Psychoanalysis... Fantazje ratunkowe i elementy utopijne w życiu i pracy Ferenczi patrz: E. Berman Ferenczi, rescue and utopia, "American Imago” 2003 No. 60, s. 429-444.

E. Berman Communal upbringing in the kibbutz: The allure and risks of psychoanalytic utopianism, "Psychoanalytic Study of the Child” 1988 No. 43, s. 319-335. education, Hachinuch Hameshutaf, I 1937 (po hebrajsku), s. 31. 
2. Ze względu na brak zaangażowania rodziców w wychowanie u dzieci mniej intensywnie rozwija się kompleks Edypa, co ratuje je przed zachorowaniem na nerwice.

3. Dzięki odseparowaniu od rodzicielskich funkcji socjalizujących i dyscyplinujących, które zostały scedowane na opiekunki, rodzice mogą dać swoim dzieciom „czystą miłość" podczas codziennych spotkań, zamiast bolesnych nakazów i zakazów wychowawczych.

Niektórzy ekstremalni kibucowi ideolodzy sugerowali, że instynktowi macierzyńskiemu należy się przeciwstawić, jako że wywodzi się on z kapitalistycznej chęci posiadania. Rodziców, którzy pragnęli mieć bliską i wyjątkową więź z dziećmi, traktowano z rezerwą i uważano za znerwicowanych i narcystycznych. Ostrzegano ich także przed zbyt intensywnym całowaniem, pieszczeniem i przytulaniem dzieci, ponieważ mogłoby to pobudzić je seksualnie.

Purytańskie podteksty tych zasad są obce Freudowi. Jednak wielu pedagogów w kibucach było przekonanych, że wyhamowanie wszelkiej aktywności seksualnej w okresie dojrzewania jest kluczowe w rozwoju ogólnego wysublimowania oraz rozbudzeniu zainteresowań społecznych i naukowych. Paradoksalnie ci sami pedagodzy zachęcali do organizowania koedukacyjnych pryszniców, przynajmniej w okresie preadolescencyjnym. Miało to prowadzić do rozwoju bardziej naturalnych i zdemistyfikowanych postaw wobec płci przeciwnej.

Ponadto wielu twórców kibuców chciało stworzyć społeczeństwo, które negowałoby wszystkie tradycyjne wartości ich europejskich rodzin, z których pochodzili. Odrzucali autorytarną kontrolę sprawowaną w patriarchalnych rodzinach dwupokoleniowych; ale mogli nie zdawać sobie sprawy, że sami nieświadomie odtwarzali spartański autorytaryzm. Presja grupy prowadziła do surowej wzajemnej kontroli wśród grup rówieśniczych. Superego osób urodzonych w kibucu często stanowi internalizację grup rówieśniczych.

Metoda ta przetrwała kilka dekad ${ }^{17}$. Długie, defensywne i bolesne dyskusje dotyczyły sceptycznych komentarzy, szczególnie takich jak Bettelheima ${ }^{18}$, który mówił o „bezbarwności i nijakości” osobowości dzieci urodzonych w kibucu ze względu na pewną płytkość wczesnego doświadczenia zarówno zaufania, jak i nieufności. Wnioski Bettelheima zostały wsparte później kilkoma

\footnotetext{
17 E. Berman Communal upbringing in the kibbutz...

18 B. Bettelheim Children of the Dream, Avon, New York 1969.
} 
projektami badawczymi oraz relacjami wielu krytycznych członków samych kibuców. Wniosek, jaki wyłonił się z badań i opowieści, był jednoznaczny: kibucowe wychowanie wspólnotowe wywiera wpływ na przyszły rozwój osobowości, powodując subtelne, ale stałe ingerencje w ekspresję emocjonalną i kreatywną oraz w jakości tworzonych związków intymnych. Rosnąca świadomość tych kosztów przyczyniła się do stopniowej zmiany w kibucach na rzecz rodzin mieszkających razem.

Z dzisiejszej perspektywy psychoanalityczne powody, dla których proponowano klasyczne wspólnotowe wychowanie, wydają się nieprzekonywające. Nauczyliśmy się doceniać pozytywny wpływ, jaki z sukcesem rozwiązany etap edypalny ma na przyszły rozwój; natomiast możliwość, że para matka-dziecko nie może się swobodnie rozwijać, wydaje się bardziej martwić teraz niż w przeszłości. Oddzielenie dyscypliny od miłości ma swoje plusy i minusy, prawdopodobnie przyczyniając się do zwiększenia rozszczepienia i do większych trudności w integracji wewnętrznych reprezentacji samego siebie i innego. Ciągłość kontaktu z jedną ważną osobą może umożliwić dziecku przejście przez pełen cykl frustracji, agresji, zdystansowania i ponownego zjednoczenia. Rosnąca złożoność teorii psychoanalitycznych sprawia, że dawny psychoanalityczny utopizm wydaje się coraz bardziej naiwny.

Zatem powszechna społeczna fantazja ratunkowa może odnieść odwrotny skutek, podobnie jak paradoksalne wyniki osobistych prób ratunku. To może prowadzić nas do rzeczowej oceny prób poprawy naszego życia emocjonalnego przez „profilaktykę zdrowia psychicznego”. Radykalne eksperymenty psychologiczne zdają się mieć coś wspólnego z entuzjastycznymi naukowymi projektami, które miały polepszyć życie przez budowanie tam, zmianę biegu rzek lub rozpylanie pestycydów - wszystkie okazały się naiwne, ponieważ nie brano pod uwagę destrukcyjnego wpływu, jaki wywarły na naturalne środowisko.

Chociaż koncentruję się tutaj na wizjach utopijnych opartych na psychoanalizie, musimy pamiętać, że wiele systemów utopijnych, religijnych i świeckich, lewicowych i mesjańskich, zawiera, jako jeden ze swoich aspektów, kreację „nowego człowieka”, ulepszonego, oczyszczonego z cech charakteru, które uważane są za zniekształcone następstwa istniejących warunków społecznych i duchowych. To jeden z głównych elementów utopijnych marksizmu, szczególnie w wersji leninowskiej, do której jeszcze powrócę. Jest on również obecny w syjonizmie, który podkreśla kontrast między wyalienowanym, uległym i słabym Żydem 
z Diaspory ${ }^{19}$ a odważnym, sprawnym i silnym „Nowym Izraelczykiem”. Powyższe przeciwstawienie było używane również w odniesieniu do Żydów zamordowanych przez nazistów (z wyjątkiem partyzantów i bojowników z getta) jako ludzi, którzy „szli jak owieczki na rzeź”. To wzgardliwe porównanie jest w ostatnich latach bardzo krytykowane w Izraelu.

Oczekiwanie, aby stworzyć „,nowego człowieka”, może prowadzić do prześladowań. We wczesnych kibucowych czasach kobieta była często oskarżana o „burżuazyjny indywidualizm”, jeśli walczyła o to, aby zostawić przy sobie niemowlę. Tak samo określano członków kibucu, którzy chcieli studiować literaturę lub fizykę bardziej niż agronomię lub inny kierunek uznawany za potrzebny do realizacji wspólnych celów.

Dążenie do stworzenia „nowego człowieka” okazuje się elementem utopijnym także w psychoanalizie. Zamiast oczyszczenia jednostki z grzechu, jak dzieje się w teologii chrześcijańskiej ${ }^{20}$, lub z burżuazyjnego indywidualizmu, jak w ideologii marksistowskiej, możemy kultywować fantazję o oczyszczeniu naszych pacjentów i kandydatów z wszelkich wyparć i represji oraz patologicznego narcyzmu. Stara wizja, by zostać w "pełni zanalizowanym” lub, jak to się przyjęło w nowszej wersji, by „osiągnąc zmianę strukturalną”, może wyrażać perfekcjonistyczne fantazje. Pozostałe ideologie mogą przywoływać ze swoich zasobów rozmaite sposoby poniżenia nieposłusznych jednostek, określając je mianem "grzesznych" lub „indywidualistycznych”; a w środowisku psychoanalityków nieposłuszny członek jest opisywany jako „niedostatecznie zanalizowany”. Jeszcze bardziej ekstremalna wersja została opisana w biografii Freuda przez Jonesa, który napisał: „Rank i Ferenczi [...] wykazywali psychotyczne objawy, które sprawiły [...] że odwracają się od Freuda i jego doktryny"21, co było całkowicie fałszywym oskarżeniem $^{22}$.

19 W niektórych tekstach syjonistów Żyd z Diaspory jest opisywany w sposób przypominający antysemickie karykatury.

Najwcześniejsza wzmianka o fantazji o Nowym Człowieku występuje w Nowym Testamencie: „że należy odrzucić starego człowieka z jego wcześniejszym sposobem życia, człowieka niszczonego przez zwodnicze żądze. Pozwólcie się odnawiać Duchowi w waszym myśleniu i przyobleczcie się w nowego człowieka, stworzonego zamysłem Boga w sprawiedliwości i prawdziwej świętości" (Ef 4,22-24). (Fragment z Biblii Paulistów, Częstochowa, 2008. - przyp. tłum.)

E. Jones The Life and Work of Sigmund Freud, vol. 3, Basic Books, New York 1957, s. 47.

C. Bonomi Flight into sanity: Jones's allegation of Ferenczi's mental deterioration reconsidered, "International Journal of Psychoanalysis" 1999 No. 80, s. 507-542. 
Balint ${ }^{23}$, Bernfeld ${ }^{24}$, Kernberg $^{25} \mathrm{i}$ inni wiodący psychoanalitycy podkreślali niebezpieczeństwo infantylizacji oraz sztywną i dokuczliwą atmosferę psychoanalitycznych programów szkoleniowych; łączę to z utopijną „fantazją o nowym człowieku". Trend ten pociąga za sobą serię perfekcjonistycznych idealizacji.

Naszym życzeniem i fantazją byłoby znalezienie najbardziej odpowiednich profesjonalistów, aby przypisać im pacjentów, którzy nadają się do analizy, z którymi mogliby ćwiczyć „odpowiednie” techniki aż do osiągnięcia strukturalnej zmiany; i aby tylko odpowiednio dobrani analitycy szkoleniowi analizowali naszych kandydatów i stale ich oceniali w celu zagwarantowania najlepszych rezultatów. Jednak to życzenie niesie ze sobą ryzykowne elementy utopijne i dlatego może prowadzić do klęski.

To życzenie-fantazja może zbytnio oddalić się od naszego klinicznego i życiowego doświadczenia ${ }^{26}$.W rzeczywistości wiemy, że my wszyscy, analitycy, na każdym etapie rozwoju zawodowego, mamy osobiste i zawodowe, mocne i słabe cechy. Każdy z nas z pewnymi pacjentami daje sobie dobrze radę, z innymi gorzej, i rzadko możemy to z góry przewidzieć. Wiemy, że na każdym szczeblu hierarchii zawodowej są koledzy, których szanujemy, i ci, wobec których mamy wątpliwości; i rzadko kiedy wszyscy zgadzają się w tych ocenach. Wiemy, że praca dobrego analityka jest kreatywna, indywidualistyczna i zawsze niestandardowa; i że wszystkie analityczne sukcesy są zawsze częściowe i że nigdy nie można wykluczyć potrzeby dalszego leczenia w przyszłości.

Osobista autonomia i autentyczny osobisty rozwój są podstawą w psychoanalizie. Jest to zawód, w którym osobowość analityka jest głównym narzędziem pracy; zawód, który bezustannie przypomina nam o iluzoryczności natury wszelkich ogólnikowych, konwencjonalnych prawd, nierozpoznanych za pośrednictwem osobistego doświadczenia. Nasza kliniczna skuteczność i teoretyczna siła zależą od elastyczności i twórczego podejścia; od

M. Balint On the psychoanalytic training system, "International Journal of Psychoanalysis" 1948 No. 29, S. 163-173.

S. Bernfeld On psychoanalytic training, „Psychoanalytic Quarterly” 1962 No. 31, s. 457-482. O.F. Kernberg The coming changes in psychoanalytic education I, "International Journal of Psychoanalysis" 2006 No. 87, S. 1649-1673. analytic Psychology” 2000 No. 17, s. 38-60. Polska wersja: „Polskie Towarzystwo Psychoanalityczne"; tegoż Impossible Training: A Relational View of Psychoanalytic Education, Analytic Press [Routledge], Hillsdale, NJ 2004. 
umiejętności pełnego wykorzystania samych siebie, aby móc nieskażonym okiem obserwować rzeczywistość emocjonalną zarówno w nas samych, jak i u innych; a także po to, aby dostrzegać nasze własne zaślepienie i sztywność, które zagradzają nam drogę. Rozwijanie tych zdolności to podstawowy cel szkolenia psychoanalitycznego; musimy zatem zwrócić szczególną uwagę na czynniki, które blokują ten rozwój.

Proporcje różnych elementów w rozwoju samego siebie jako analityka mogą być rozmaite. Są aspekty rozwijane wewnętrznie przez proces indywidualizacji, po krytyczne przyswajanie i procesowanie, które pozwala na odkrycie, jakim analitykiem chcę i potrafię zostać; oraz aspekty determinowane z zewnątrz, kształtowane przez spełnianie oczekiwań, na co wpływa w zbyt dużym stopniu aspekt osobowości, który można by nazwać fałszywym analitycznym self.

Analityczne fałszywe self różni się oczywiście od wcześniejszego, podstawowego pojęcia Fałszywego Self (False Self) opisanego przez Winnicotta ${ }^{27}$, ale pojęcia te mają pewne wspólne cechy. Tutaj także osoba "zostaje skuszona do podporządkowania się, a podporządkowane Fałszywe Self spełnia oczekiwania otoczenia [...] i poprzez introjekcje może uzyskać złudzenie bycia prawdziwym" ${ }^{28}$."Dziecko może stać się takie samo jak matka, opiekunka, ciotka, brat lub ktokolwiek inny, kto w tym czasie dominuje na scenie". Podobnie kandydat w szkoleniu analitycznym może zapragnąć, by stać się takim jak analitycy szkoleniowi, którzy przewodzą w jego środowisku.

Podejrzewam, że istnieje wiele pozornie udanych prób ukształtowania oczyszczonych Nowych Ludzi - w kontekście religijnym, politycznym i narodowym - które są wariacją zjawiska Fałszywego Self. Możemy stanąć wobec podobnych zagrożeń w psychoanalitycznej społeczności. Pokusa przynależności, bycia akceptowanym, bycia lubianym przez wyższych od siebie rangą jest silna i w wielu przypadkach może mieć decydujące znaczenie.

Wnioski te prowadzą nas znowu na grunt polityczny. Jakub Talmon ${ }^{29}$, wybitny izraelski historyk, pisze o „klątwie wiszącej nad wizjami zbawienia: rodzą się z najszlachetniejszych pobudek, a degenerują się w narzędzia tyranii". Dobrym przykładem tego zagrożenia jest etos komunistyczny, w którym rycerz-wybawca (rewolucjoniści) miał uratować ofiarę (proletariat) ze

27 D.W. Winnicott Ego distortion in terms of true and false self, w: The Maturational Processes and the Facilitating Environment, Hogarth, London 1960.

28 Tamże, s. 146.

29 J.L. Talmon (1952) Źródła demokracji totalitarnej, Universitas, Kraków 2015, S. 253. 
szponów przerażającego smoka (uciskający ich wróg klasowy). Wizja ta zaślepiła pokolenia idealistów z całego świata do tego stopnia, że nie byli w stanie zdać sobie sprawy z tego, że „rycerz zamienił się w smoka” i rewolucjoniści stali się tyranami. Od „nowego człowieka” sowieckiej kultury oczekiwano poświęcenia wszystkich osobistych potrzeb i czasami jego więzi rodzinnych, tylko w imię służenia wspólnemu dobru „ludu” ściśle definiowanemu przez przywódców partii komunistycznej.

Z perspektywy czasu można ocenić, że próby wykucia „nowego człowieka" i „nowego społeczeństwa" doprowadziły ostatecznie - już po upadku komunizmu i państwa represyjnego - do dużej regresji w kierunku cynizmu, mistycyzmu i szowinizmu. Narody postkomunistyczne porzuciły poprzednią ideologię, ale zachowały pewną komunistyczną nieugiętość (Sebek ${ }^{30}$ pisze o „posttotalitarnej osobowości”), która może mieć wpływ na myślenie psychoanalityczne w tych kulturach.

Łatwo pomylić krytykę utopizmu z krytyką wszelkich zmian społecznych z perspektywy konserwatywnych politycznych uprzedzeń. Jednakże utopizm różni się od realistycznych innowacyjności społecznych tym samym, czym różnił się „ratunek” od rzeczywistej pomocy terapeutycznej: omnipotencją, idealizacją siebie, uromantycznieniem, demonizowaniem winnego wroga (projekcja złego), niezdolnością do dostrzegania złożoności procesów społecznych i także paradoksalnych i nieprzewidywalnych skutków radykalnych zmian. Iluzja prowadzi do rozczarowania, a nie do postępu.

Ponadto wierzę, że utopizm często niszczy ruchy polityczne dążące do zmiany społecznej. Kiedy np. ruch pokojowy przyswaja pacyfistyczne utopijne przekonanie, że w przyszłości ludzkość się zjednoczy i nie będzie występowała agresja, nie będzie granic ani innych podziałów, to staje się on niezdolny do dostrzeżenia intensywnych uczuć narodowych większości ludzi. Zdolność ruchu do moderowania narodowych animozji spada, zamiast się polepszać przez odseparowanie od rzeczywistych emocji ludzi, od ich dumy, agresji i lęków ${ }^{31}$.

Talmon we wnioskach do książki Źródła demokracji totalitarnej ${ }^{32}$ stwierdza: „Totalitarno-demokratyczne nieporozumienie czy samozakłamanie stanowi

M. Sebek Posttotalitarian personality - old internal objects in a new situation, "Journal of the American Academy of Psychoanalysis" 1998 No. 26, s. 295-309. tyn - Polskie Towarzystwo Psychoanalityczne" 2015 nr 30, s. 70-82.

32 J.L. Talmon (1952) Źródła demokracji totalitarnej... 
[...] reductio ad absurdum racjonalistycznej koncepcji człowieka rodem z XVIII wieku; spaczona idea zrodziła irracjonalną wiarę $\mathrm{w}$ to, że pozaracjonalne pierwiastki w naturze ludzkiej [...] są niefortunnym przypadkiem, przykrą pozostałością lub chwilową aberracją, które w swoim czasie i pod wpływem odpowiedniej terapii ustąpią miejsca jednolicie racjonalnemu zachowaniu w zintegrowanym społeczeństwie. [...] Podobnie jak psychoanalityk, który leczy pacjenta uświadamiając mu treści jego podświadomości, analityk społeczny może zaatakować ludzki impuls, który powołuje do istnienia totalitarną demokrację; innymi słowy, ludzką tęsknotę za ostatecznym rozwikłaniem wszelkich sprzeczności w stanie doskonałej harmonii. Niewdzięcznym, ale koniecznym zadaniem jest wpojenie ludziom tej prawdy, że społeczeństwo i życie ludzkie nigdy nie osiągną stanu spoczynku"33.

Sugeruję, aby psychoanalityk był nie tylko modelem, ale także partnerem w próbie odejścia od tego niebezpiecznego pragnienia dzięki głębszemu psychologicznemu pojmowaniu. Echo wniosków historyka słychać u psychoanalityków Chasseguet-Smirgel i Grunbergera ${ }^{34}$, którzy opisują utopijne fantazje i ich iluzoryczną naturę następująco: „Gdy już jest oczyszczona z niegodziwości, które to mogą być reprezentowane przez Żydów, własność prywatną, kapitalizm, społeczeństwo patriarchalne, zbroja charakteru, lub jakikolwiek inny projektowany obiek $\mathrm{t}^{35}$, oczyszczone ego może istnieć bez konfliktu, człowiek może zjednoczyć się z Bogiem. [...] Paul Nizan pisze: kiedy człowiek stanie się pełnią i będzie wolny, wtedy już nie będzie marzył po nocach. Innymi słowy, wierzy, że wszystko, czego pragnie, zostanie spełnione. Jednakże psychoanaliza utrzymuje, że ludzka niepełność, a więc ludzkie pragnienia, nigdy nie przestaną istnieć. Ludzkość jest skazana na marzenia od teraz do wieczności".

Przełożyła Aleksandra Pieńkowska

Tamże, s. 200.

J. Chasseguet-Smirgel, B. Grunberger Freud or Reich?, Yale University Press, New Haven 1986, S. 213 .

Można dodać tutaj scenę pierwotną, role genderowe, maltretowanie dzieci itd. 


\section{Abstract}

\section{Emanuel Berman}

UNIVERSITY OF HAIFA

\section{Psychoanalysis and Utopia}

There are parallels between three movements that blossomed during the first decades of the twentieth century: Marxism, Zionism and psychoanalysis. Utopian elements were present in all three, expressing a deep commitment to improving human life, but also aspects of denial and illusion that led to more complex results than initially expected. Rescue fantasies played a role in these movements, implying omnipotence, self-idealization and the demonization of a guilty party. The kibbutz movement in Israel was influenced by all three, and its communal childrearing system proved to be flawed. Dangers of rigidity and dogmatism in psychoanalysis are related to this background.

\section{Keywords}

authoritarianism, communist ethos, false analytic self, infantilization, Middle East, New Person fantasy, pacifism, peer group, primal scene, 'Vertigo'. 